\title{
Major Production Problems of Dairy Cows of Different Farm Scales Located in the Capital City Addis Ababa, Ethiopia
}

Seble Aweke* and Berhanu Mekibib

Ethiopian Ministry of Animal health and Fisheries, Bishoftu, Oromia Ethiopia

*Corresponding author: Seble Aweke Tolera, Ethiopian Ministry of Animal health and Fisheries, Bishoftu, Oromia Ethiopia, Tel: +254-20 422 3000; E-mail: sebaweke@gmail.com

Rec date: October 04, 2017; Acc date: October 31, 2017; Pub date: November 02, 2017

Copyright: (C) 2017 Aweke S, et al. This is an open-access article distributed under the terms of the Creative Commons Attribution License, which permits unrestricted use, distribution, and reproduction in any medium, provided the original author and source are credited.

\begin{abstract}
The study deals with major production problem of selected dairy farms in Addis Ababa from November 2009 to April 2010. The study covered 31 farms grouped in to three production systems, namely 13 small scale (SS) with 260 cows, 9 medium scales (MS) (451) and 9 large scales (LS) (1543) dairy cows. Demographic characteristics of farm owners of studied farms was female dominated in SS $(53.3 \%)$ while in MS (55.5\%) and LS $(77.8 \%)$ was male dominated. Farm owner's literacy rate was $100 \%$ in medium and LS farms while $92.3 \%$ in SS farm. In the studied farms, pure exotic cows were dominant in all types of scales; $61.5 \%, 55.6 \%$ and $88.9 \%$ in SS, MS and LS, respectively. The breeding systems used in the farms was commonly artificial insemination (Al) in SS (100\%) and MS (77.7\%) while in LS, both $\mathrm{Al}$ and the combination of $\mathrm{Al}$ and natural mating, each contributed $44.4 \%$. Furthermore, the major reasons of culling were health related in both SS and MS accounted, $69.2 \%$ and $44.4 \%$, respectively. However, in LS low productivity $(77.8 \%)$ was dominant. Data on feeding management indicated that hay and wheat bran was dominant feed types in all types of scales in which most of them fed their animals twice a day. The survey also showed health problems encountered (from 2007/8 to 2009/10) in different scales as repeat breeding and mastitis more common in SS $(25.8 \%$ and $25.4 \%)$ and MS $(13.4 \%$ and $10.4 \%)$ while in LS, mastitis and hypocalcemia was more common (both accounted for $8 \%$ ). The main prevention in the farm was vaccination. In conclusion, identification of the diary bottleneck is critical to solve and rise their production. So, most health and management problems encountered can possibly corrected with raising awareness and follow-up of farms with professionals before further damage on this emerging industry.
\end{abstract}

Keywords: Addis Ababa; Dairy production problems; Dairy farm; Mastitis; Questionnaire survey; Repeat breeding

\section{Introduction}

Ethiopia is a country with higher human population estimated to be more than 94 million [1]. This huge population rely mainly on agriculture including their livestock income. The country is believed to have the largest livestock population in Africa [2,3]. An estimate showed, the country is a home for about 54 million cattle, 25.5 million sheep and 24.06 million goats. From the total cattle population $98.95 \%$ are local breeds and the remaining are hybrid and exotic breeds. $99.8 \%$ of the sheep and nearly all goat population of the country are local breeds [2]. Endogenous cattle are thought to be adapted to prevailing environmental condition though their milk production potential is lower (on average $213 \mathrm{~kg} / \mathrm{cow}$ per lactation) [4] than that of exotic breeds in temperate region (on average $5800 \mathrm{~kg} / \mathrm{cow} / \mathrm{lactation}$ ) [5].

Livestock performs multiple functions in the Ethiopian household economy by providing food, input for crop production and soil fertility management, cash income as well as in promoting savings, fuel, social functions, and employments. With these multiple functions, livestock can serve as a vehicle for improving food security and better livelihood of the rural population [6].

Ethiopia produces approximately 3.2 billion litres from 10 million milking cows-an average of 1.54 litres per cow per day over a lactation period of 180 days [7]. In the country, urban and peri-urban dairy production system are emerging as an important component of the milk production system contributing immensely toward filling the larger gap for milk and milk product supplement. These is evident in urban centers where consumption of milk and milk product is remarkably high [4]. In the capital city, Addis Ababa, the highest expenditure group, which makes up around $10 \%$ of the market, consumes $38 \%$ of the milk. On the other hand, $61 \%$ of the population who are in the lowest expenditure group, consumed only $23 \%$ of the milk. To fulfill the increased demand of milk for urban and peri-urban consumers of the country, significant effect has been made to increase the genetic make-up of local dairy cow by improving dairy breed [8]. Even though, the livestock sector has a significant contribution to the national economy, animal productivity is extremely low. This is evidenced by the very low per capita consumption of protein and a very low growth rate of milk and meat production that is below the recommended average rate needed to feed the growing population [9].

The low productivity in dairy sector is due to many factors mentioned for the existing problems in the country. This is associated with multiple inter-related factors such as inadequate feed and nutrition, widespread diseases, poor genetic potential of local breeds, market problem, inefficiency of livestock development services with respect to credit, extension, marketing, and infrastructure [10]. Furthermore, in depth identification of those problems in the sector regarding husbandry and health issue is important. Those identified problems correlated to distinct types of production scale is also important to tackle the existing problems in the dairy farm industry. Therefore, the objective of this study was aimed to understand the conditions of dairy production systems and assess major problems observed in dairy farms in Addis Ababa. 
Page 2 of 6

\section{Materials and Methods}

\section{Study area}

The study was conducted at Addis Ababa, in the capital city of Ethiopia. Addis Ababa lies in the central highlands of Ethiopia at an altitude of 2500 meters above sea level; the average annual temperature and rainfall are $21^{\circ} \mathrm{C}$ and $1800 \mathrm{~mm}$ respectively. The relative humidity varies from 70 to $80 \%$ during the rainy season and from 40 to $50 \%$ during the dry season. Addis Ababa and its peri-urban areas have 62,166 bovines, 22,647 ovine, 7,531 equines, 5,597 caprine and 330,000 avian species [11].

\section{Study design and sampling method}

The cross-sectional study of data collection was carried out from November 2009 to April 2010 in different (small, medium and large) scales of dairy farms in the selected areas of Addis Ababa. Sampling of the dairy farms were randomly but with a consent and willingness in sharing their recorded data also taken in to consideration. So, after random sampling if the consent and willingness of the owner was not there the next draw was taken in to consideration. Likewise, 31 different scale farms were included in the study.

\section{Study population}

The study population include 31 dairy cow farms selected for the study purpose. For convenience, the farms were grouped in to 3 categories; small (farms having $\leq 10$ dairy cows), medium (farms having [11 to 20]) and large scales (farms having $\geq 21$ dairy cows). Total population of dairy cows' present were 260 for small scale, 451 for medium scale and 1,543 for large scale dairy farms. Those dairy cows were pure breeds of Holstein Frisian and cross breeds that kept for milk production purpose.

\section{Study methodology}

Dairy farm locations were gathered and stratification was made to different categories and random sampling was employed to select dairy farms of different category representative for the study. The categories made was as small, medium and large scale based on herd size; having $\leq 10$ (small scale farm), [11-20] (Medium scale farm) and 21 and above dairy cows (Large scale farm). After the stratification was made based on different scales which followed by simple random sampling in each stratum. Accordingly, 13 small, 9 medium and 9 large-scale dairy farms were selected. The relevant information regarding the health status and management system of the farms was collected by structured interview (predesigned questionnaire format) and detail assessment of record of the farm notebook. For some of the dairy farm health problems like mastitis, retained placenta, bloat and uterine prolapse observation was made with a coincidence and cross-check their diagnosis. Moreover, the health management aspects in terms of vaccination, treatment approaches in which they rely to treat their dairy cows was recovered from the recorded data from 2007/8 to 2009/10 record (three years) and via questionnaire.

\section{Questionnaire survey}

A detailed and organized questionnaire format was used to generate base line information related to dairy farms demographic characteristics and other related aspects (cattle breed, breeding method, reasons for culling, herd structure management, housing and feeding), major dairy cattle health problems and veterinary services. All owners of the dairy farms $(n=31)$ were involved in the interview.

Secondary data of three years was used (from 2007/8 to 2009/10) to look for health constraints and related factors in the farms. Those data were used to assess dairy health problems, veterinary services and prophylaxis measures.

\section{Active observational survey}

During the visit in to the farms, observation was made to look for different farm structures and status like their hygiene and status of drainage of the house etc.

\section{Data management and analysis}

Data obtained from questionnaire and observational study were entered Microsoft Excel spread sheet and coded appropriately. Data were analyzed using STATA version 11 for windows (2007), from which descriptive statistics were used to summarize the results from questionnaire and secondary data (Frequencies/numbers, mean and percentage).

\section{Results}

\section{Husbandry and management}

Most dairy farm owners were having medium and large-scale dairy farms were male which is $55.5 \%$ and $77.8 \%$, respectively while proportional sex ratio of small scale owners was observed. Age distribution of farm owner's showed variability as the maximum and minimum age of farm owners in all scales of dairy farms were 28 and 71 years old, respectively. (Table 1 ).

\begin{tabular}{|l|l|l|l|}
\hline $\begin{array}{l}\text { Production system (Farm } \\
\text { size) }\end{array}$ & Male (\%) & Female (\%) & Total (\%) \\
\hline Small scale (SS) & $6(46.2)$ & $7(53.8)$ & $13(41.9)$ \\
\hline Medium Scale (MS) & $5(55.5)$ & $4(44.4)$ & $9(29)$ \\
\hline Large scale (LS) & $7(77.8)$ & $2(22.2)$ & $9(29)$ \\
\hline Total & 18 & 13 & $31(100)$ \\
\hline
\end{tabular}

Table1: Farm owners' demographic characteristics $(\mathrm{N}=31)$.

Educational status of the farm owners showed; literacy rate in small, medium and large scale were $92.3 \%, 100 \%$ and $100 \%$, respectively. Accordingly, there was no illiterate farm owners in medium and largescale dairy farms (Table 2).

\begin{tabular}{|l|l|l|l|l|}
\hline \multirow{2}{*}{$\begin{array}{l}\text { Educational } \\
\text { level }\end{array}$} & \multicolumn{2}{|l|}{ Production system } & \multirow{2}{*}{ Total } \\
\cline { 2 - 4 } & $\begin{array}{l}\text { Small scale } \\
\text { (SS) }\end{array}$ & $\begin{array}{l}\text { Medium scale } \\
\text { (MS) }\end{array}$ & $\begin{array}{l}\text { Large scale } \\
\text { (LS) }\end{array}$ & \multirow{2}{*}{1} \\
\hline Illiterate & 1 & 0 & 0 & 3 \\
\hline Basic writing & 3 & 0 & 0 & 12 \\
\hline Elementary & 5 & 4 & 3 & $16(55.2)$ \\
\hline Total (\%) & $9(69.2)$ & $4(50)$ & $3(37.5)$ & 9 \\
\hline High school & 2 & 3 & 4 & \\
\hline
\end{tabular}


Page 3 of 6

\begin{tabular}{|l|l|l|l|l|}
\hline $\begin{array}{l}\text { Higher } \\
\text { education }\end{array}$ & 2 & 1 & 1 & 4 \\
\hline Summary & 13 & 8 & 8 & 29 \\
\hline $\begin{array}{l}\text { Literacy rate } \\
(\%)\end{array}$ & 92.3 & 100 & 100 & 96.6 \\
\hline
\end{tabular}

Table 2: Educational Status of different scales of dairy farm owners.

Farmers under small, medium and large-scale dairy farming possessed majorly pure exotic cattle breed which was $61 \%, 55.6 \%$ and $88.9 \%$, respectively. Regarding the breeding method of the farms, $11.1 \%$ of dairy farm owners in large scale production system use bulls (natural mating) for breeding purpose, whereas none of the small-scale dairy farming use bulls for breeding. There were different culling systems practiced in the studied dairy farms which include health problem, feed shortage and low production were identified as the main culling reasons in small, medium and large-scale productions with $69.2 \%, 22.2 \%$ and $100 \%$ frequencies, respectively (Table 3 ).

\begin{tabular}{|l|l|l|l|}
\hline & \multicolumn{3}{|c|}{ Production systems } \\
\hline Variables & SS (n=13) & MS(n=9) & LS(n=9) \\
\hline Cattle breed & & & \\
\hline Pure exotic & $8(61.5 \%)$ & $5(55.6 \%)$ & $8(88.9 \%)$ \\
\hline Cross & $5(38.5 \%)$ & $3(33.3 \%)$ & $1(11.1 \%)$ \\
\hline Both & 0 & $1(11.1 \%)$ & 0 \\
\hline Method of breeding & & & $4(44.4 \%)$ \\
\hline $\begin{array}{l}\text { Artificial insemination } \\
\text { (Al) }\end{array}$ & $13(100 \%)$ & $7(77.7 \%)$ & $1(11.1 \%)$ \\
\hline Bull (Natural mating) & 0 & 0 & $4(44.4 \%)$ \\
\hline Both & 0 & $2(22.2 \%)$ & \\
\hline $\begin{array}{l}\text { Major causes for } \\
\text { culling }\end{array}$ & & & $7(77.8 \%)$ \\
\hline Low productivity & $1(7.7 \%)$ & $2(22.2 \%)$ & 0 \\
\hline Feed shortage & $1(7.7 \%)$ & $2(22.2 \%)$ & $2(22.2 \%)$ \\
\hline Health related & $9(69.2 \%)$ & $4(44.4 \%)$ & 0 \\
\hline $\begin{array}{l}\text { Financial } \\
\text { requirement }\end{array}$ & $2(15.4 \%)$ & $1(11.1 \%)$ & \\
\hline
\end{tabular}

Table 3: Proportions of farms in the use of different methods of breeding systems and their major culling reasons their owned dairy cow breeds.

The housing condition of the farms varied among different production scales. Likewise, $61.1 \%$ of small scale dairy farm floor type was soil or sandy while $77.7 \%$ of medium scale and $88.9 \%$ of large scale dairy farming system floor types were concrete. Regarding the ventilation of the pen, $76.9 \%, 55.5 \%$ and $33.3 \%$ of poor ventilation were observed in small, medium and large-scale productions. In addition, medium and large-scale farms showed relatively good drainage system, that was $44.4 \%$ and $77.8 \%$, respectively (Table 4 ).

\begin{tabular}{|l|l|l|}
\hline Variables & Category & Production system \\
\hline
\end{tabular}

\begin{tabular}{|l|l|l|l|l|}
\hline \multirow{2}{*}{ Type of floors } & SS (n=13) & MS (n=9) & LS (n=9) \\
\cline { 2 - 5 } & Soil/sandy & $8(61.5 \%)$ & $8(88.9 \%)$ & $1(11.1 \%)$ \\
\hline \multirow{2}{*}{$\begin{array}{l}\text { Drainage } \\
\text { system }\end{array}$} & Good & $5(38.5 \%)$ & $7(77.8 \%)$ & $8(88.9 \%)$ \\
\cline { 2 - 5 } & Satisfactory & $2(15.4 \%)$ & $1(11.1 \%)$ & 0 \\
\cline { 2 - 5 } & Poor & $7(53.8 \%)$ & $4(44.4 \%)$ & $2(22.2 \%)$ \\
\hline \multirow{2}{*}{$\begin{array}{l}\text { Ventilation } \\
\text { system }\end{array}$} & Good & $2(15.4 \%)$ & $4(44.4 \%)$ & $5(55.5)$ \\
\cline { 2 - 5 } & Satisfactory & $3(23.1 \%)$ & 0 & $2(22.2 \%)$ \\
\cline { 2 - 5 } & Poor & $8(61.5 \%)$ & $5(55.6 \%)$ & $2(22.2 \%)$ \\
\hline
\end{tabular}

Table 4: Housing conditions of the dairy farms $(\mathrm{N}=31)$.

\section{Feeding system at farm level}

$88.8 \%$ and $11.1 \%$ in small and medium scale dairy farming, respectively use feeding their cows on the ground whereas none of large scale farms feed on their animal on ground. In all scales of dairy farms, hay and wheat bran were the major feed types. Concerning watering and water availability $100 \%, 66.6 \%$ and $44.4 \%$ of small scale, medium scale and large-scale dairy farms have access to drink water twice a day (Table 5).

\begin{tabular}{|c|c|c|c|c|}
\hline \multirow{2}{*}{ Variable } & \multirow{2}{*}{ Category } & \multicolumn{3}{|c|}{ Production systems } \\
\hline & & ss & MS & LS \\
\hline \multirow{3}{*}{$\begin{array}{l}\text { Feeding } \\
\text { system }\end{array}$} & $\begin{array}{l}\text { Common } \\
\text { trough }\end{array}$ & $4(30.8 \%)$ & $6(66.6 \%)$ & $3(33.3 \%)$ \\
\hline & $\begin{array}{l}\text { Separate } \\
\text { trough }\end{array}$ & $1(7.7 \%)$ & $2(22.2 \%)$ & $6(6.6 \%)$ \\
\hline & Ground & $8(88.8 \%)$ & $1(11.1 \%)$ & 0 \\
\hline \multirow{6}{*}{ Types of feed } & Cotton seed & 9 & 6 & 8 \\
\hline & Nuge cake & 8 & 6 & 6 \\
\hline & $\begin{array}{l}\text { Brewery } \\
\text { product }\end{array}$ & 4 & 5 & 5 \\
\hline & Mitin & 3 & 2 & 3 \\
\hline & Straw & 2 & 2 & 2 \\
\hline & $\begin{array}{l}\text { Hay and } \\
\text { wheat bran }\end{array}$ & $13(100 \%)$ & $9(100 \%)$ & $9(100 \%)$ \\
\hline \multirow{3}{*}{$\begin{array}{l}\text { Frequency of } \\
\text { watering }\end{array}$} & One times/day & 0 & 0 & $1(11.1 \%)$ \\
\hline & Two times/day & $13(100 \%)$ & $6(66.6 \%)$ & $4(44.4 \%)$ \\
\hline & $\begin{array}{l}\text { Three } \\
\text { times/day }\end{array}$ & 0 & $3(33.3 \%)$ & $4(44.4 \%)$ \\
\hline
\end{tabular}

Table 5: Type of major feed stuff, feeding systems and availability of water practiced in Addis Ababa dairy farms. 'Mitin'- locally formulated ration containing bone meal, limestone, salt, wheat etc. 
Page 4 of 6

\section{Common dairy cattle problems}

From 31 dairy farms categorized in to three different scales; 260 dairy cows in small scales of 13 farms, 451 in medium scales of 9 farms and 1,543 in large scale of 9 farms were recorded. In those farms 12 different dairy cow problems were gathered from record with the higher percentage of repeat breeding in small $(25.8 \%)$ and medium scale (13.1\%) while mastitis and hypocalcemia was higher in percentage (both $8 \%$ ) in large scale dairy farm. On the other hand, lowest disease and/or signs recovered from record were uterine prolapse in small scale $(0.4 \%)$ and large scale $(0.2 \%)$, and Bloat and Diarrhea in medium scale (both $1.1 \%$ ) (Table 6).

\begin{tabular}{|l|l|l|l|}
\hline \multirow{2}{*}{ Cases } & \multicolumn{3}{|l|}{ Production systems } \\
\cline { 2 - 4 } & $\%$ in SS & $\%$ in MS & $\%$ in LS \\
\hline Dystocia & 2.3 & 3.8 & 0.8 \\
\hline Abortion & 2.3 & 2 & 2.3 \\
\hline Retained placenta & 7.7 & 3.5 & 3.4 \\
\hline $\begin{array}{l}\text { Calf death of unknown } \\
\text { cause }\end{array}$ & 7.3 & 3.3 & 1 \\
\hline Repeat breeding & 25.8 & 13.1 & 4.1 \\
\hline Uterine prolapse & 0.4 & 2.2 & 0.2 \\
\hline Mastitis & 25.4 & 10.4 & 8 \\
\hline Pneumonia & 6.2 & 3 & 4.5 \\
\hline Lameness & 4.2 & 3 & 2 \\
\hline Hypocalcemia & 2 & 4.5 & 8 \\
\hline Bloat & 2.7 & 1.1 & 0.2 \\
\hline Diarrhea & 1.2 & 1.1 & 3.4 \\
\hline
\end{tabular}

Table 6: The average percentage of common dairy health problems encountered from $2007 / 8$ to $2009 / 10$ in different scales of farming system $(\mathrm{N}=31)$.

$100 \%$ of large scale farm practiced vaccination in the three consecutive years from 2007/8 to 2009/10. The record also showed the common vaccines given in all three scales were against blackleg, anthrax, pasteurellosis, lumpy skin disease or stationary veterinary service and foot and mouth disease on annual basis. All small scale of dairy production systems gets veterinary service from the government, while $11.1 \%$ of medium scale farm use self-treatment (nonprofessionals like the owner or manager of the farm). On the other hand, $55.6 \%$ of large scale dairy farming system hire their own professionals (Veterinarian or animal health professionals) to treat their dairy cows (Table 7).

\begin{tabular}{|l|l|l|l|}
\hline \multirow{2}{*}{ Category } & \multicolumn{3}{l|}{ Production system } \\
\cline { 2 - 4 } & SS & MS & LS \\
\hline Vaccination per years & & & \\
\hline $2007 / 8$ & $6(46.1 \%)$ & $7(77.7 \%)$ & $9(100 \%)$ \\
\hline $2008 / 9$ & $6(46.1 \%)$ & $6(66.6 \%)$ & $9(100 \%)$ \\
\hline $2009 / 10$ & $8(61.5 \%)$ & $7(77.7 \%)$ & $9(100 \%)$ \\
\hline
\end{tabular}

\begin{tabular}{|l|l|l|l|}
\hline Veterinary service & & & \\
\hline $\begin{array}{l}\text { Stationary veterinary/ } \\
\text { On call/government }\end{array}$ & $13(100 \%)$ & $8(88.9 \%)$ & $5(55.6 \%)$ \\
\hline Self-treatment & 0 & $1(11.1 \%)$ & $1(11.1 \%)$ \\
\hline Private & 0 & 0 & $3(33.3 \%)$ \\
\hline
\end{tabular}

Table 7: Prophylaxis measure given from 2007/8 to 2009/10.

\section{Discussion}

A cross-sectional study was conducted in selected dairy farms of Addis Ababa from November 2009 to April 2010. This study revealed different health and management problems of dairy farms of different scales. Among these; mastitis, repeat breeding, retained placenta, feeding and watering system, housing pattern, labor constraints and land shortage showed to be prevail in the study areas.

The education status of each farming system was diverse but most of them got educational status that ranges from illiterate to elementary (55.2\%). Literacy rate (i.e. excluding illiterate but includes basic writing, primary, high school and higher education) of dairy farm owners were $96.6 \%$. However, Lemma et al. reported relatively smaller literacy rate $(79.4 \%)$ of household head-education level from Bishoftu town, $45 \mathrm{~km}$ away from Addis Ababa [12].

Dairy farms in the study area regardless of their production system was dominated by pure exotic breeds. Accordingly, small, medium and large-scale farms owned $61.5 \%, 55.6 \%$ and $88.9 \%$ of their dairy cows were pure exotic breed, respectively. Their preference is because of their high yielding capacity and financial return. However, since these breeds are less likely adapted to a relatively harsh tropical climatic condition and unimproved production system, as in our case, they are more prone to disease conditions.

In this study, in the small-scale dairy farming, artificial insemination (AI) was the only option (100\%) for breeding purpose. This is mainly due to shortage of space and difficulties of management including shortage of feed to keep another animal (i.e. Bull). However, in large scale dairy farms all types of breeding methods were observed; AI (44.4\%), Bull (natural mating) (11.1\%) and Both AI and natural mating combined in $44.4 \%$ of dairy farms. In contrary, Kastros reported that the use of local bull for breeding was the primary option for most farmers $(77.5 \%)$ while $22.5 \%$ practice AI in Alaba Woreda of SNNPs [13]. The difference observed in the breeding system used in these two study areas reflect the variation in the availability of AI service and space for keeping and managing bulls.

Health problems in small scale (69.2\%), and medium scale (44.4\%) while low production was found to dominate for culling in large scale (100\%) dairy farms. However, in all forms of farming system, it was common to maintain unproductive animal, specially animal with poor reproductive performance. On the other hand, farm owners having smaller herd size usually keep cows for household with mild supply of locally available feeds with the minimum cost possible with the exception in large scale dairy farms. Large scale dairy farms primarily intended as an investment and hence the financial return from milk or sell of animal was the critical point that determines the culling rate on cows with poor productivity.

The observed poor housing system, particularly in small and medium scale dairy farming systems, potentially affect the productivity 
and health of the herd. Confined farm premises were observed in both small and medium scale dairy farms which expose to poor ventilation. Poor ventilated house, where considerable number of animals confined in small space, may lead to respiratory infection [14]. Moreover, in all scales of dairy farming systems, all dairy cattle were managed together, and calves kept in one corner of the same house or rarely in separate house. The need to group cows based on their physiological status, production or reproduction was reported as mandatory, mainly in large herds [15]. The environment, particularly the house, directly and indirectly influences survival and productivity of dairy animals [16]. Degree of environmental impact, be it poor ventilation or housing of multiple age groups in the same house, can be modified by stage of life cycle and adaptations of given breeds. Calves, being naive for the environment, are the first to face environmental problems and the pathogens shaded from adapted/mature room-mates. Calf morbidity and mortality rates are usually higher in calves housed indoors, specially with other age groups, than outdoors. The increased illness and mortality in calves that are reared indoors with others is often attributed to a combination of inadequate control of thermal environment, poor air quality, undesirable relative humidity, inadequate exchange of air and poor sanitation [17].

Regarding feeding among different farm scales; hay and wheat bran were the main feed type used by all three scales. In line with this, Yoseph et al. reported that hay is the most common feed resource in urban and peri-urban dairy farms in Ethiopia [18]. In the study area, pasture grazing was not common, which was comparable with Yoseph which was conducted in urban and peri urban dairy production of central Ethiopia and reported semi zero road side and public open field grazing as a source of feed [19]. Dairy farmers in the urban areas mainly used purchased roughage and concentrate feed. Most of the dairy farms in three scales fed their animals two times a day (i.e. morning and night).

The variation in the feeding system and practice observed among the three production systems as feeding on ground (88.8\%) in small scale, on common trough for medium (66.6\%) and large scale $(33.3 \%)$ was found to be the dominant one. The variation could be associated with the cost of construction, lack of man power to put the feed in the troughs or the ease of leftovers cleaning. However, the use of separate trough can reduce competition among animals and hence trauma and some diseases like actinobacillosis and actinomycosis. In contrary, ground feeding system ( $\mathrm{SS}=88.8, \mathrm{MS}=11.1 \%$ and $\mathrm{LS}=0$ ), the frequent method observed in most small-scale dairy farms (88.8\%), can increase feed contamination and hence diseases occurrence.

Animal health is one of the many factors that affect economic efficiency of dairy herd. Among the reproductive disorders, repeat breeding $(25.8 \%)$ and mastitis $(25.4 \%)$ was abundant in small scale (SS) as $25.8 \%$ and $25.4 \%$, and in medium scale (MS) as $13.4 \%$ and $10.4 \%$, respectively. However, mastitis and hypocalcemia was more common in large scale (LS) (both accounted for 8\%). The abundance in repeat breeding in SS and MS could be due to lack of "on time" AI service, poor heat detection ability of herdsmen, unsatisfactory postproduction handling of $\mathrm{AI}$ and the general health status of the cow.

Mastitis has been known to cause a great deal of loss or reduction of productivity, to influence the quality and quantity of milk yield, and to cause culling of animals at an unacceptable age. Clinical mastitis was the second most common production problem following repeat breeding in all the scales of dairy production and accounted for $25.4 \%$, $10.4 \%$ and $8.0 \%$ in small, medium and large-scale dairy farming systems, respectively. The problem was observed in a higher frequency in small scale production system than once occurring in medium and large-scale production. Such variation in the frequency of clinical mastitis could be associated with poor sanitary measures taken for the house, the cow and the udder in small scale production system. Relating to this, $10.6 \%$ mastitis by Gebremedhin [20] and $11.8 \%$ by Edilu [21] et al. was found to be a major health problem of small holder dairy farmers in Atsbi Womberta Woreda, Tigray Regional State and West Shewa Zone, Oromia, Ethiopia, respectively. Even though the findings of the current study relied on retrospective data, it was not difficult to estimate the overall prevalence of mastitis (both clinical and sub-clinical). Moreover, the figures described above were only those that were clinically detected by milkers, herdsmen and/or veterinarian in charge. However, study conducted in and around Sebata by Sori reported $52.78 \%$ of overall mastitis prevalence [22]. The variability in the prevalence of bovine mastitis between reports could be attributed to difference in management of the farms, availability of veterinary service, breeds and other factors.

Other diseases of reproductive disorders like retained placenta $(7.7 \%)$ and calf mortality $(7.3 \%)$ were higher in small scale dairy production system than the rest. In contrast to this, Yoseph et al. reported retained placenta (14.7\%) as the most important reproductive health problems in large scale dairy production system than others [18]. Nevertheless, Weaver and Goodgur suggest that the rate of dystocia, retained placenta and postpartum uterine infection have been found to be less than 10\% [23]. Additionally, Scott and Kennedy and Beck et al. find out that mastitis and retained placenta are known diseases that cause heavy economic losses to milk producers and the dairy industry by reducing the quantity and quality of milk output, increase veterinary expenses due to excessive use of medication [24,25].

For most dairy herds, the single most important means of increasing income is increasing the number of calves, the future of any dairy production. According to Kifaro and Temba, calf morbidity and mortality are recurrent problems in all countries and calf mortality as high as $5 \%$ considered to be tolerable [26]. However, high rates of dairy calf mortality as observed in small scale dairy farms of the present study $(7.3 \%)$, questions the success of any dairy enterprise. Under most conditions, the average length of time a cow stays in a milking herd is about four years and, therefore, $25 \%$ of the milking herd must be replaced each year [27]. This makes the cost of raising dairy replacement heifer substantial and only next to feed [28].

Pneumonia was also observed in all scales of the dairy farming system. But it was relatively higher in small scale (6.2\%) dairy farming system. The potential causes for these includes, confinement of cows with poor ventilation, poor management and feeding system practiced. The lameness was also observed to be $4.5 \%$ in small and 3\% in medium scale, while it was $2 \%$ in large scale. Potentially this can be contributed by poor floor design, the presence of poor drainage that causes the house suitable for pathogens and harshly animal handling practice.

In conclusion, the major production problems indicated in this study includes poor management and feeding system, insufficient AI services, calf death, health related problems like mastitis, retained placenta, pneumonia and repeat breeding were commonly found in the all studied farm scales. These multidirectional viewed problems have caused and are causing devastating economic losses in the study areas. As to recommendation, improvement of the quality and quantity of feed offered and the overall management cow would result in better input. In addition to improved management, increase production of milk cross breed indigenous cattle with exotic cattle breed can be 
planned and to be implement in the area. Herd management is a major key in meeting the highest potential of milk production in each cow. Careful health management of the cow as comfortable as possible and reduce many elements of stress that would adversely affect animal production which further boost the production output.

\section{Conflict of interests}

The authors have not declared any conflict of interest.

\section{Acknowledgements}

We would like to thank Hawassa University for funding the research and subjects involved in the research; farm owner's and personnel working in the premises.

\section{References}

1. Central Statistical Authority (CSA) (2017) Federal Democratic Republic of Ethiopia.

2. Central Statistical Authority (CSA) (2013) Agricultural Sample Survey, 2012/13 (2005 EC), Volume II: Report on Livestock and livestock characteristics (Private peasant holdings). Statistical Bulletin 570. Addis Ababa: Central Statistical Agency (CSA), Federal Democratic Republic of Ethiopia.

3. Tilahun H, Schmidt E (2012) Spatial Analysis of Livestock Production Patterns in Ethiopia. ESSP II Working Paper 44. Addis Ababa, Ethiopia: International Food Policy Research Institute/Ethiopia Strategy Support Program II.

4. Azage T, Alemu GW (1997) Prospects for peri-urban dairy development in Ethiopia. In: Proceedings of the Fifth National Conference of the Ethiopian Society of Animal Production, Addis Ababa, Ethiopia. pp: 28-39.

5. deLeeuw PN, Omore A, Staal S, Thorpe W (1999) Dairy production system in the tropics. In: Smallholder Dairy in the Tropics. ILRI. Kenya. Diseases of cattle, sheep, pigs, goats and horses, 8th edn. Baillaiaere Tindall, London.

6. Ethiopia Dairy Value Chains (2010) The next stage in dairy development for Ethiopia: Dairy Value Chains, End Markets and Food Security. USAID CA No. 663-A-00-05-00431-00 Land O’Lakes, Inc. IDD.

7. Tefera TL (2010) "Commercializing dairy and forage systems in Ethiopia: An Innovation Systems Perspective." ILRI-IPMS. Working Paper No. 17.

8. Abaye T, Alemu G, Bemk Y, Philip C (1991) Status of Dairying in Ethiopia and Strategies for Future Development. The Third National Livestock Improvement Conference Institute of Agricultural Research (IAR) Addis Ababa, Ethiopia.

9. Sendros D, Tesfaye K (1997) Factors to be considered in the formulation of livestock breeding policy. In: Proceedings of the Fifth National Conference of ESAP, Addis Ababa, Ethiopia, pp: 13-27.

10. Negassa A, Rashid S, Gebremedhin B (2011) Livestock Production and Marketing. ESSP II Working Paper 26. Addis Ababa, Ethiopia: International Food Policy Research Institute/Ethiopia Strategy Support Program II.

11. Central Statistical Authority (CSA) (2009) Federal Democratic Republic of Ethiopia, Central Statistical Authority (CSA), Agricultural Sample
Survey 2008/2009 [2001 EC], Report on Livestock and Livestock Characteristics, Addis Ababa, p: 120.

12. Lemma HD, Mengistu A, Kuma T, Kuma B (2017) The potential of milk production and consumption for improving nutrition of smallholder dairy households in Ethiopia. Milk Dairy Prod Human Nutrition 70: $10-16$.

13. Kastros M (2007) Major animal health problems of market oriented livestock development in Alaba woreda, Southern Nations Nationalities and People's Region, DVM thesis, Addis Ababa university, Ethiopia.

14. Quinn PJ, Carter ME, Markey B, Carter GR (1994) Clinical Veterinary Microbiology. Wolfe Publishing, London, pp. 21-179.

15. Radostits OM, Gay CC, Blood DC, Hinch Cliff KW (2000) Veterinary Medicine; A text book of the diseases of cattle, sheep, pigs, goats and horses. 9th edn. New York, Saunders Company. Ltd., pp: 1-45.

16. Thatcher WW, Collier, RJ (1981) Effect of heat on animal productivity. In: Handbook of agricultural productivity. CRC Press, Boca Raton, Florida, USA, pp: 77.

17. Blowey RW (1990) Veterinary Book for Dairy Farmers. 2nd edn. Ipswich: Farming press Ltd. pp: 15-33.

18. Yoseph S, Tenhagen B A, Merga B, Tesfu K (2005) Reproductive disorders of crossbred dairy cows in the Centeral Highlands of Ethiopia and their effect on reproductive performance. Trop Anim Health Prod 37: 427-441.

19. Yoseph M (1999) Impact of feed resources on productive and reproductive performance of dairy cows in the urban and peri-urban dairy production system in the Addis Ababa milk shed and evaluation of non- conventional feed resources using sheep. MSc Thesis, Alemaya University, Ethiopia.

20. Gebremedhin A (2007) Major animal health problems of market oriented livestock development in Atsbi womberta woreda, Tigray regional state. DVM thesis, Addis Ababa Ethiopia.

21. Edilu J, Bizunesh M, Hirut AA, Waktole T, Mekonen S, et al. (2016) Study on Prevalence of Major Health Problem of Dairy Cattle in Selected Towns of West Shewa Zone, Oromia, Ethiopia. Glob Vet 16: 165-171.

22. Sori H, Zerihun A, Abdicho S (2005) Dairy cattle mastitis in and around Sebeta, Ethiopia. Intern J Appl Res Vet Med 3: 332-338.

23. Weaver LB, Goodgur WJ (1987) Design and economic evaluation of dairy reproductive health program for large dairy herds. In Herd Health (edition): Food Animal Production Medicine, 2nd edn. Philadelphia: WE Sounders company, Wolfe publishing, London, pp. 175-179.

24. Scott AW, Kennedy JO (1993) The economics of culling dairy cows with clinical mastitis. Vet Res 133: 494-498.

25. Beck HS, Wise WS, Dodd FH (1992). Cost benefit analysis of bovine mastitis in the UK. J Dairy Res 59: 449-460.

26. Kifaro GC, Temba EA (1990) Calf mortality and culling rate in two dairy farms in Iringa region, Tanzania. In proceeding of Tanzania society of Animal production (TSAP). Tanzania, pp.138-149.

27. Bath DL, Dickinson FR, Tucker HA, Appleman RD (1985) Dairy Cattle: Problems, Practices, Problems and Profits, 3rd edn. Philadelphia: Lea and Febiger, Pp: 325-338.

28. Heinrichs AJ, Radostits OM (2001) Health and production management of dairy calves and replacement heifers. In: Radostits OM (ed.): Herd Health, Food Animal Production Medicine, 3rd edn. Philadelphia, WB Saunders Company, pp: 333-395. 